\title{
Autologous and homologous transplantation of bovine spermatogonial stem cells
}

\author{
F. Izadyar ${ }^{1,2}$, K. Den Ouden ${ }^{1,2}$, T. A. E. Stout ${ }^{4}$, J. Stout ${ }^{3}$, J. Coret $^{3}$, D. P. K. Lankveld ${ }^{4}$, \\ T. J. P. Spoormakers ${ }^{4}$, B. Colenbrander ${ }^{4}$, J. K. Oldenbroek ${ }^{5}$, K. D. Van der Ploeg ${ }^{5}$, \\ H. Woelders ${ }^{5}$, H. B. Kal ${ }^{3}$ and D. G. De Rooij ${ }^{1,2}$
}

\begin{abstract}
${ }^{1}$ Department of Endocrinology, Faculty of Biology, Utrecht University, Utrecht, The Netherlands; Departments of ${ }^{2}$ Cell Biology and ${ }^{3}$ Radiotherapy, University Medical Center Utrecht, Utrecht, The Netherlands; ${ }^{4}$ Department of Equine Sciences, Faculty of Veterinary Medicine, Utrecht University, Utrecht, The Netherlands; and ${ }^{5}$ Division of Animal Sciences, ID-Lelystad, Lelystad, The Netherlands
\end{abstract}

The aim of this study was to develop a method for spermatogonial stem cell transplantation into the bovine testis. Five-month-old Holstein-Friesian calves were used and half of the calves were hemicastrated to allow autologous transplantation and the other half were used for homologous transplantation. Approximately $20 \mathrm{~g}$ of each testis was used for cell isolation. On average $10^{6}$ cells per gram of testis containing about $70 \%$ type A spermatogonia were isolated. The cells were frozen in liquid nitrogen until transplantation. Testes were irradiated locally with 10-14 Gy of Xrays to deplete endogenous spermatogenesis. At 2 months after irradiation, cells (approximately $10 \times 10^{6}$ ) were injected into the rete testis through a long injection needle (18 gauge), using ultrasonography and an ultrasound contrast solution. At 2.5 months after transplantation, calves were castrated and samples of testes were taken for histological examination. After 2.5 months in the irradiated non-transplanted control testes, only $45 \%$ of the tubules contained type A spermatogonia. However, after autologous spermatogonial transplantation, $>80 \%$ of the tubule cross-sections contained type A spermatogonia. In addition, only $20 \%$ of the tubules of the control testes contained spermatocytes and, except for a few tubules $(5 \%)$ with round spermatids, no more advanced germ cells were found. After autologous spermatogonial transplantation, about $60 \%$ of the tubules contained spermatocytes; $30 \%$ contained spermatids and in about $15 \%$ of tubules spermatozoa were found. No improvement in spermatogonial repopulation was found after homologous transplantation. The results of this study demonstrate, for the first time, successful autologous transplantation of bovine spermatogonial stem cells resulting in a complete regeneration of spermatogenesis.

\section{Introduction}

Spermatogenesis is a highly organized process which is initiated and maintained by continuous proliferation and differentiation of spermatogonial stem cells. In many non-primate mammals, including rodents and sheep, the so-called $A$ single $\left(A_{s}\right)$ spermatogonia are the stem cells of spermatogenesis (Huckins, 1971; Lok et al., 1982; de Rooij and Grootegoed, 1998). After a number of spermatogonial divisions, these cells give rise to spermatocytes, which after the meiotic divisions produce spermatids that develop into spermatozoa.

Spermatogonial stem cell transplantation in rodents offers unique strategies for the analysis of germ cell development. After the original breakthrough in rodents (Brinster and Avarbock, 1994; Brinster and Zimmermann, 1994), various modifications and many new approaches

Email: F.Izadyar@vet.uu.nl have been described in different species. This technique was used to investigate the behaviour of spermatogonia from a variety of species, including rats (Clouthier et al., 1996), hamsters (Ogawa et al., 1999a), rabbits and dogs (Dobrinski et al., 1999), large domestic species (Dobrinski et al., 2000; Izadyar et al., 2002a), primates (Nagano et al., 2001) and humans (Nagano et al., 2002), in recipient mouse testes. These studies consistently showed that the success of heterologous transplantation is dependent on the phylogenic distance between the donor and the recipient species. As in cell suspensions, spermatogonial stem cells cannot be morphologically distinguished from other type A spermatogonia, and as only the stem cells are able to colonize and repopulate the testes, transplantation has become a functional assay for spermatogonial stem cell activity (Shinohara et al., 2000a). This assay was also used to study surface markers on spermatogonial stem cells (Shinohara et al., 2000b) and to determine genes (Boettger-Tong et al., 2000) 
and factors involved in regulation of proliferation and differentiation of spermatogonial stem cells (Ohta et al., 2000, 2001).

It also appeared that removal of endogenous stem cells from the recipient testis is important for spermatogonial transplantation (Ogawa et al., 1999b). Endogenous spermatogenesis was blocked in the host testis mainly by using cytotoxic treatment with busulfan. In addition, in most of the studies, immunodeficient mice were used as recipients to avoid rejection of transplanted spermatogonia. It is clear that immunodeficiency is essential for heterologous transplantation (from one species to another); however, it is not clear to what extent immunodeficiency is critical for homologous transplantation. It has been shown that homologous transplantation of spermatogonia in pigs and goats is as efficient as autologous transplantion in terms of colonization (Honaramooz et al., 2002; 2003). However, complete regeneration of spermatogenesis was not observed in pigs after autologous or homologous transplantation.

Creemers et al. (2002) developed a method for depletion of endogenous spermatogenesis within recipient mouse testes using local fractionated X-irradiation. This method resulted in $>95 \%$ of empty tubules after 1 month of irradiation without any apparent effect on the somatic Sertoli cells. These mice were later used as recipients in a variety of transplantation studies and could be colonized by mouse (Creemers et al., 2002), rat (van Pelt et al., 2002) and bovine (Izadyar et al., 2002a) spermatogonia.

An ultrasound-guided injection of testis has been described by Schlatt et al. (1999). In the present study, a more efficient protocol was developed for injecting the rete testis in bulls using an ultrasound contrast solution. In addition, purified bovine type A spermatogonia were transplanted into the testes of recipient calves of which endogenous spermatogenesis was depleted by local $X$-irradiation. The efficiency of transplantation was assessed after autologous and homologous attempts using histological and immunohistological studies.

\section{Materials and Methods}

\section{Anaesthesia and castration procedures}

The experimental protocol of this study followed the Guidelines for Care and Use of Laboratory Animals and was approved by the Animal Care and Use Committee of the Utrecht University. Fourteen Holstein-Friesian calves of 5 months old were used in the present study. Half of the calves were hemicastrated to allow autologous transplantation and the other half were used for homologous transplantation. For all animals, food was withheld for $18 \mathrm{~h}$ before anaesthesia, but water was always available. Before premedication with detomidine (Domosedan ${ }^{\circledR}$, Pfizer Animal Health B.V., Capelle a/d IJssel, $10 \mu \mathrm{g}$ $\mathrm{kg}^{-1}$, i.v.) an $8 \mathrm{~cm} 12 \mathrm{G}$ Teflon catheter (Intraflon $2^{\circledR}$, Vygon Nederland B.V., Veenendaal) was inserted into the jugular vein. As soon as premedication took effect, anaesthesia was induced with midazolam $\left(0.06 \mathrm{mg} \mathrm{kg}^{-1}\right)$ and ketamine $\left(\right.$ Narketan $^{\circledR}$, Chassot, Hasselt, $2.2 \mathrm{mg}$ $\mathrm{kg}^{-1}$ ). Maintenance of anaesthesia was achieved by infusion of a combination of guaiphenesin (Gujatal ${ }^{\circledR}$, Eurovet, Bladel, $\left.100.0 \mathrm{mg} \mathrm{ml}^{-1}\right)$, ketamine $\left(2.0 \mathrm{mg} \mathrm{ml}^{-1}\right)$ and detomidine $\left(0.02 \mathrm{mg} \mathrm{ml}^{-1}\right)$ ('triple-drip-infusion'). The initial infusion rate was $0.02 \mathrm{ml} \mathrm{kg}^{-1} \mathrm{~min}^{-1}$, which was adjusted on the basis of clinical signs. Simultaneously, a Ringer infusion was administered $(0.05 \mathrm{ml}$ $\mathrm{kg}^{-1} \min ^{-1}$ ). Supplementary oxygen was administered through a small nose tube. At the end of anaesthesia, detomidine effects were antagonized by atipamezole (Antisedan ${ }^{\circledR}$, Pfizer Animal Health B.V., $10 \mu \mathrm{g} \mathrm{kg}{ }^{-1}$, i.v.). This protocol was used for each anaesthesia in the whole experiment. The average time of anaesthesia needed for hemicastration, radiation therapy, transplantation and the final castration or hemicastration was 10, 20, 15 and $12 \mathrm{~min}$, respectively. For castration, the animal was positioned in lateral recumbency. For hemicastration, a scalpel blade was used to make an incision in the lateral scrotal wall in a vertical direction. When both testes had to be removed, the distal part of the scrotum was removed. In both techniques, the spermatic cord was ligated with USP 2 polyglactin 910 (Vicryl ${ }^{\circledR}$, Ethicon, Brussels) and subsequently sharply transected. Skin wounds were left open to heal by second intention. After castration, flunixine meglumine (Finadyne ${ }^{\circledR}$, Schering-Plough B.V., Maarssen, $1.1 \mathrm{mg}$ $\mathrm{kg}^{-1}$, i.v.) and procainepenicillin-G (Depocilline ${ }^{\circledR}, \mathrm{My}$ cofarm Nederland B.V., de Bilt, $20000 \mathrm{IU} \mathrm{kg}^{-1}$ ) were administered i.m. All recoveries from anaesthesia and surgery were smooth and without any complications.

\section{Preparation of donor cells and cryopreservation}

After hemicastration, the testes were transferred on ice to the laboratory. A sample was taken for protein extraction and histological examination, and approximately $20 \mathrm{~g}$ of each testis was used for cell isolation, as described by Izadyar et al. (2002a). On average $10^{6}$ cells per gram of testis containing about $70 \%$ of type A spermatogonia were isolated. Viability of cells after isolation was always $>90 \%$. The cells were mixed with the freezing medium containing $10 \%(\mathrm{v} / \mathrm{v})$ dimethyl sulphoxide and $10 \%(\mathrm{v} / \mathrm{v})$ fetal calf serum supplemented with 0.07 mol sucrose $\mathrm{I}^{-1}$, which has been shown to be beneficial for cryopreservation of bovine type A spermatogonia (Izadyar et al., 2002b), and frozen in liquid nitrogen until transplantation. On the day of transplantation, cells were thawed at $38^{\circ} \mathrm{C}$ for $30 \mathrm{~s}$ and, after viability assessment, were resuspended in $3 \mathrm{ml}$ minimum essential medium containing $1 \%$ BSA and transferred on ice to the farm for transplantation. With this protocol, $70 \%$ of cells survived cryopreservation and could be used for transplantation. 


\section{Preparation of recipient bulls}

Two groups of recipients were used. One group was hemicastrated and received their own cells (autologous) and the other group which retained two testes received cells from other calves (homologous). In the case of autologous transplantation, a period of 2 weeks was allowed for the animals to recover and heal from hemicastration before irradiation. For irradiation, calves were anaesthetized as described above and maintained in the lateral position. The testes with $2 \mathrm{~cm}$ build-up material were irradiated with single graded doses of 10-14 Gy using $6 \mathrm{MV} \mathrm{X}$-rays; the dose rate was approximately $3 \mathrm{~Gy}$ $\min ^{-1}$ (Philips SL25 linear accelerator, Eindhoven).

\section{Rete testis injection and transplantation}

For the development of the rete testis injection procedure, testes from twelve calves between the ages of 5 and 12 months were collected from the abattoir. Three injection methods were used and for each method eight testes were injected. The first method was an injection without use of ultrasonography (blind injection). A long injection needle (18 gauge) was inserted along the midline of the testis through the epididymis. Subsequently, a syringe was connected to the needle and a blue dye was injected slowly $\left(1 \mathrm{ml} \mathrm{min} \mathrm{m}^{-1}\right)$ allowing the injection site and the efficiency of each injection to be traced. The second method used an ultrasound guided injection and a blue dye was injected in the testes. A $7.5 \mathrm{mHtz}$ transducer (Piomedicals) was used and an image from three perpendicular levels was taken to find the mediastinum and to insert the needle in that area; however, it was not possible to guide the needle into the rete testes using ultrasonography alone. Therefore, a contrast solution Levovist (Shering, Berlin) was used. Levovist is a powder which mainly (99\%) contains galactose and when mixed with water makes micro-bubbles of 2-3 $\mu \mathrm{m}$ which are stable for $30 \mathrm{~min}$. Studies in human medicine have shown that this solution can be injected safely into various tissues and that it produces a very good contrast in ultrasonography (Almeida et al., 2002; Hansberg et al., 2002). Two recommended concentrations (200 and $400 \mathrm{mg} \mathrm{ml}^{-1}$ ) were tested. In addition, the required volume to fill the testis was determined. The efficiency of Levovist in ultrasonography of a living calf was tested by injecting only one tesis as the other testis was used as the control. In addition, for determination of the toxicity of Levovist for donor cells, different concentrations (200 and $400 \mathrm{mg} \mathrm{ml}^{-1}$ ) of Levovist were added to purified type A spermatogonia and the viability of these cells was assessed after 6 and $24 \mathrm{~h}$ of culture.

For transplantation at 2 months after irradiation, calves were anaesthetized as described above and under aseptic conditions a long injection needle (18 gauge) was inserted into the mediastinum using ultrasonography. The needle was guided in the rete testes by injecting
$1 \mathrm{ml}$ Levovist as described above and cells $\left(5-10 \times 10^{6}\right)$ were injected into the rete testis with the velocity of $1 \mathrm{ml}$ $\min ^{-1}$. Six calves received their own cells (autologous) and another six calves received cells from other calves (homologous) in one testis and the other testis was used as control. In addition, two other calves received only medium (sham transplantation).

\section{Evaluation of recipient testes after transplantation}

At 2.5 months after transplantation, calves were castrated and testes were weighed. On account of the large size of the testes in this species and to include the whole testes for a reliable comparison between the animals, each testis was cut in eight parts and from each part some samples were fixed in Bouin's solution, preserved in $70 \%(\mathrm{v} / \mathrm{v})$ ethanol and then embedded in paraffin wax for histological or immunohistological studies. For histological staining, sections of $5 \mu \mathrm{m}$ in thickness were mounted on Tespa-coated glass slides. The paraffin wax was removed and after rehydration through a graded series of alcohol the sections were stained with periodic acid-Schiff and haematoxylin, and then dehydrated and mounted under a coverslip with Pertex (Cell Path, Compulink). The sections were analysed under a light microscope and images were taken with a digital camera (Nikon, Tokyo). For immunohistochemical staining of Dolichos biflorus agglutinin (DBA), sections of $7 \mu \mathrm{m}$ in thickness were used, the sections were deparaffinized, rehydrated and were transferred into 0.1 mol PBS $\mathrm{I}^{-1}$. The lectin DBA (E.Y. laboratories, San Mateo, CA) was used, as described by Ertl and Wrobel (1992), to identify type A spermatogonia.

\section{Statistical analysis}

The results are presented as means \pm SEM unless otherwise indicated. Statistical analysis was performed by two-sample $t$ test and the difference was considered significant at $P<0.05$.

\section{Results}

\section{Development of a rete testes injection method}

From the eight testes used for injection without ultrasound guidance, only one was injected properly. Application of ultrasonography markedly improved the injection efficiency and four of the eight testes were injected properly. Although, ultrasonography helped to locate the mediastinum and to insert the needle in this area, it was not possible to guide the needle into the rete testes; therefore, the contrast solution Levovist was used. Two recommended concentrations (200 and $400 \mathrm{mg} \mathrm{ml}^{-1}$ ) were tested and both concentrations resulted in a good contrast in the testes; therefore, $200 \mathrm{mg} \mathrm{ml}^{-1}$ was used for the present study. Injection of Levovist into the testis 

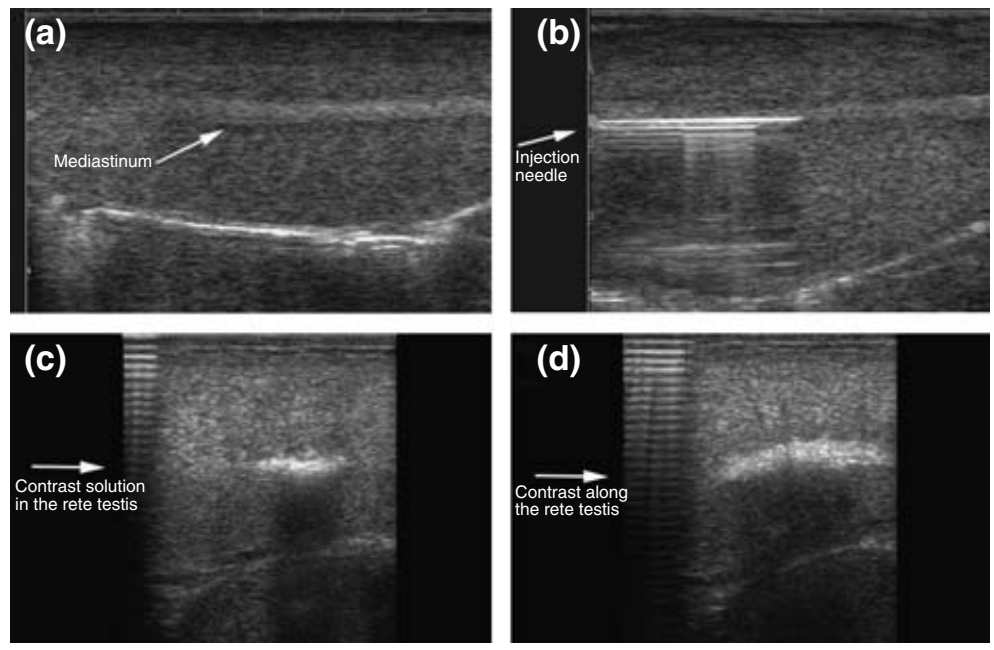

Fig. 1. Injection of the bovine rete testes using ultrasonography and contrast solution Levovist. (a) Note the presence of a longitudinal mediastinum in the middle of the testis. (b) A long injection needle inserted from the epididymis towards the mediastinum. (c,d) Immediately after injection, a uniform distribution of the contrast solution along the rete testes was observed.

gave a clear contrast at the injection site and when the needle was placed in the rete testes, a longitudinal distribution of the contrast along the rete testes and even in the seminiferous tubules could be seen (Fig. 1). Application of Levovist further enhanced the injection efficiency and in this case six of the eight testes were injected properly. In general, injection in larger testes was easier than in smaller ones.

A volume of $3.5 \mathrm{ml}$ of the cell suspension was found to be enough to fill the testis of a 5-month-old calf. After the injection procedure was optimized using testes obtained from an abattoir, the efficiency was tested in the testis of a live calf. The distribution of the contrast solution in testes of live calves was similar to that in testes collected from the abattoir. In addition, no harmful effect of Levovist was observed on testis morphology or function, as found by repeated ultrasonography after injection and subsequent histological examination. Moreover, no harmful effect of Levovist on the viability of purified type A spermatogonia was found during a $24 \mathrm{~h}$ incubation (Table 1). No difference was found in the success of injection between the groups.

\section{Analysis of recipient testes after transplantation}

Several parameters have been used to determine the efficiency of transplantation. First, testicular mass was assessed. Testes from 5-month-old calves weighed $34.5 \pm 3.8 \mathrm{~g}$. After irradiation and 2.5 months after transplantation, the calves were 10 months old and the average testis mass of each animal $(n=2)$ in the sham group was $41.2 \mathrm{~g}$. An almost threefold increase in testis mass
Table 1. The effect of Levovist on the viability of a pure population of bovine type A spermatogonia after isolation and after $24 \mathrm{~h}$ of culture

\begin{tabular}{ccc}
\hline $\begin{array}{l}\text { Levovist } \\
\left(\mathrm{mg} \mathrm{ml}^{-1}\right)\end{array}$ & $\begin{array}{c}\text { Living cells at } \\
\text { time } 0 \mathrm{~h}(\%)\end{array}$ & $\begin{array}{c}\text { Living cells after } \\
24 \mathrm{~h}(\%)\end{array}$ \\
\hline 0 & $79.5 \pm 3.5$ & $69.2 \pm 2.9$ \\
200 & $82.5 \pm 4.1$ & $67.4 \pm 3.8$ \\
400 & $83.3 \pm 3.2$ & $68.8 \pm 3.5$ \\
\hline
\end{tabular}

Type A spermatogonia were isolated from 5-month-old calf testis and cultured as described by Izadyar et al. (2003). Sperm viability was assessed by a live and dead kit (Molecular Probes). This experiment consisted of three replicates.

was observed after autologous transplantation $(106.7 \pm$ 13.5); however, after homologous transplantation testis mass $(47.7 \pm 10.6 \mathrm{~g})$ was very similar to that of the nontransplanted control testis (Fig. 2). In addition, a clear difference in testis histology between the non-transplanted and the transplanted group was observed only after autologous transplantation. Spermatogenesis was restored in $>80 \%$ of the calves after autologous transplantation, whereas only $20 \%$ of the calves showed a regeneration in spermatogenesis after homologous transplantation (Table 2). Histological examination showed that at 5 months of age almost all the tubule cross-sections contain type A spermatogonia. After hemicastration, irradiation and sham transplantation, $>60 \%$ of tubules contained no germ cells and in tubules that did contain germ cells the number of type A spermatogonia was clearly decreased at 5 months after irradiation. In addition, only $20 \%$ of the tubules of the sham group contained 
Table 2. Efficiency of autologous or homologous transplantation of bovine type A spermatogonia

\begin{tabular}{lccc}
\hline $\begin{array}{l}\text { Type of } \\
\text { transplantation }\end{array}$ & $\begin{array}{c}\text { Number } \\
\text { of calves }\end{array}$ & $\begin{array}{c}\text { Calves showing } \\
\text { enhanced colonization (\%) }\end{array}$ & $\begin{array}{c}\text { Calves showing } \\
\text { enhanced spermatogenesis (\%) }\end{array}$ \\
\hline Autologous & 6 & $5 / 6(83.3)$ & $5 / 6(83.3)$ \\
Homologous & 5 & $1 / 5(20.0)$ & $1 / 5(20.0)$ \\
\hline
\end{tabular}

The results are from two separate experiments. At 2.5 months after transplantation, the colonization efficiency was assessed by Dolichos biflorus agglutinin staining and spermatogenesis was evaluated by histological examination.

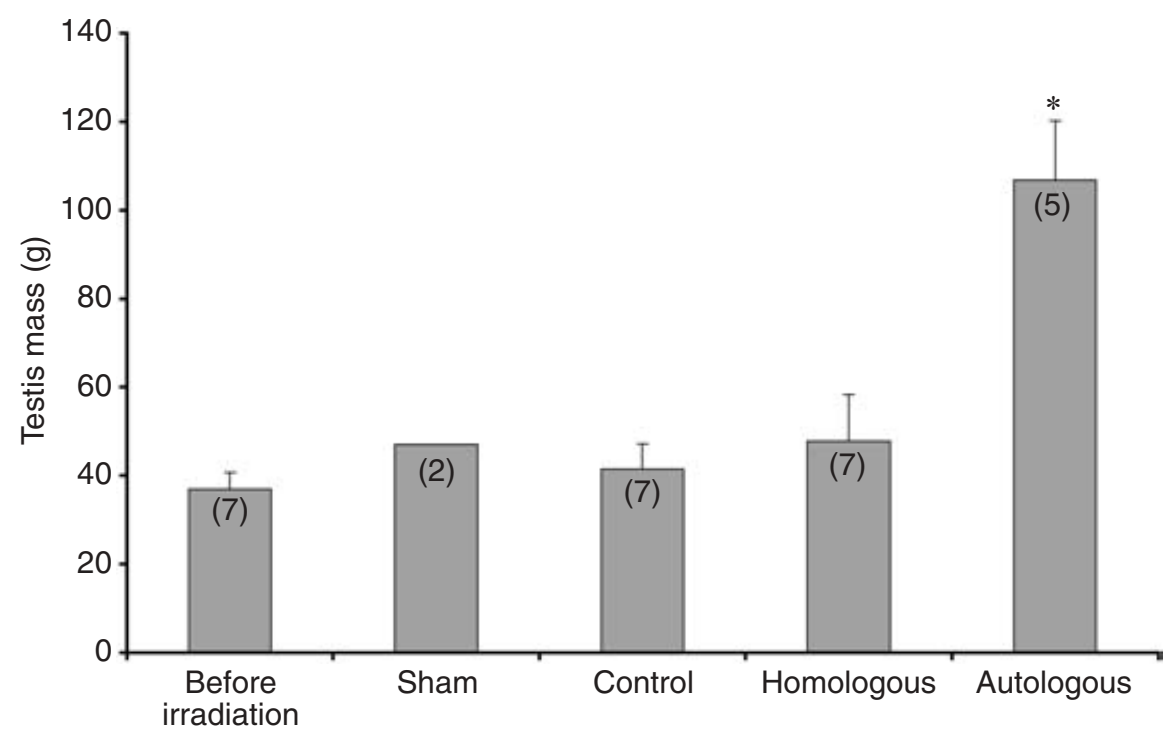

Fig. 2. Bovine testes mass before irradiation and 2.5 months after sham or spermatogonial transplantation. The results are the pool of two separate experiments. The values in the columns represent the number of testes examined. *Note that a significant $(P<0.001)$ difference was observed only after autologous transplantation.

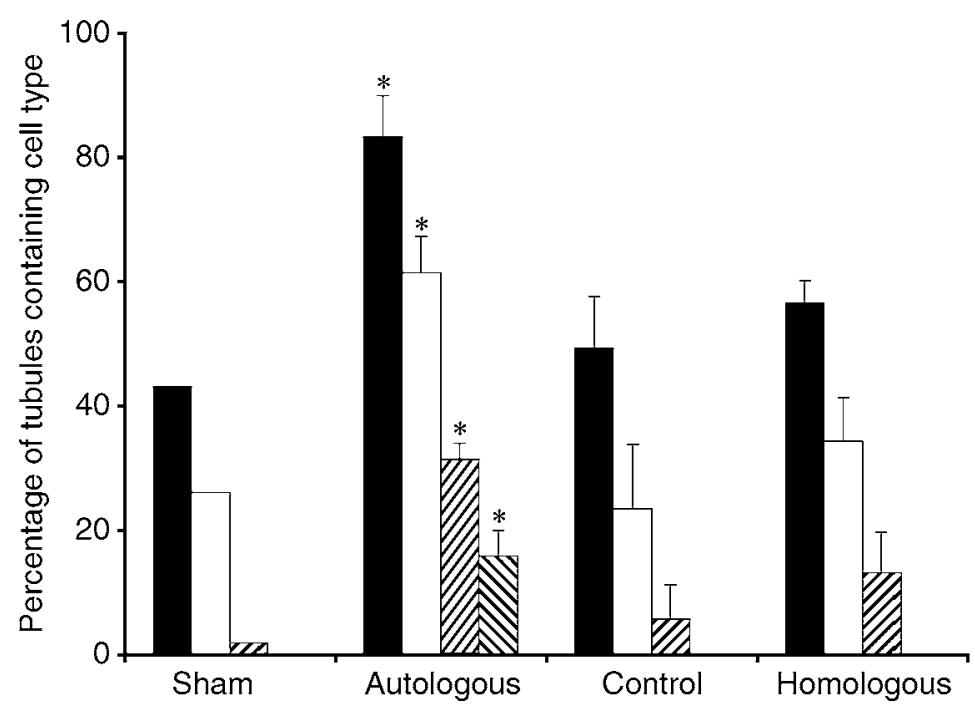

Fig. 3. Germ cells present in calf testes 2.5 months after sham or spermatogonial stem cell transplantation. The results are the mean \pm SEM of two separate experiments. A significant $(P<0.01)$ difference was observed only after autologous transplantation (asterisks). $\mathbf{~ : ~ s p e r m a t o g o n i a ; ~ ( ~} \square$ ): spermato-

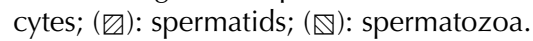



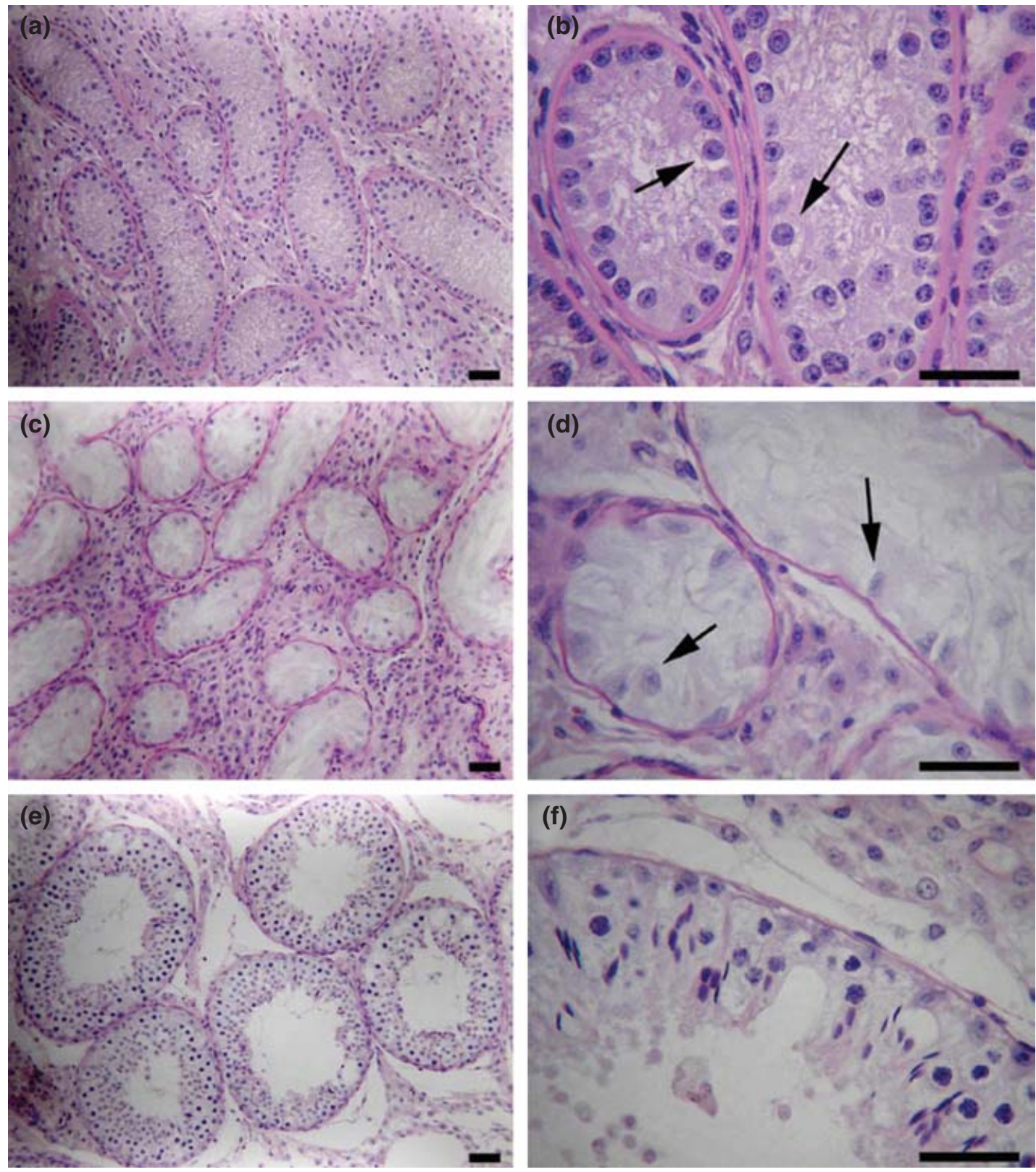

Fig. 4. Bovine testes histology before irradiation and 2.5 months after sham or spermatogonial stem cell transplantation. (a) Testis histology before irradiation. (b) The same section as in (a) at a higher magnification. Note type A spermatogonia is the predominant type of germ cells in the testis (arrows). (c). Tubule cross-section of a calf 2.5 months after sham transplantation. (d) The same section as in (c) at a higher magnification. Note that after irradiation, the population of spermatogonia has decreased markedly and many tubules contained only Sertoli cells (arrows). (e) Tubular cross section of a calf 2.5 months after autologous spermatogonial transplantation. Note that most of the tubules show spermatogenesis and more advanced germ cells were found. $(f)$ The same section as in (e) at a higher magnification. Scale bars represent $50 \mu \mathrm{m}$.

spermatocytes and no more advanced germ cells were found. Testes of calves that were not hemicastrated but were irradiated but not transplanted (control group) also showed the same germ cell distribution. However, after autologous spermatogonial transplantation, $83 \pm 3.5 \%$ of the tubule cross-sections contained type A spermatogonia, $>60 \%$ of the tubules contained spermatocytes, $30 \%$ contained spermatids and spermatozoa were found in about $15 \%$ of tubules (Figs 3 and 4 ). Furthermore, both the percentage of tubules containing type A spermatogonia and the number of type A spermatogonia per tubule cross-section increased after autologous transplantation, but not after homologous transplantation (Figs 5 and 6). 


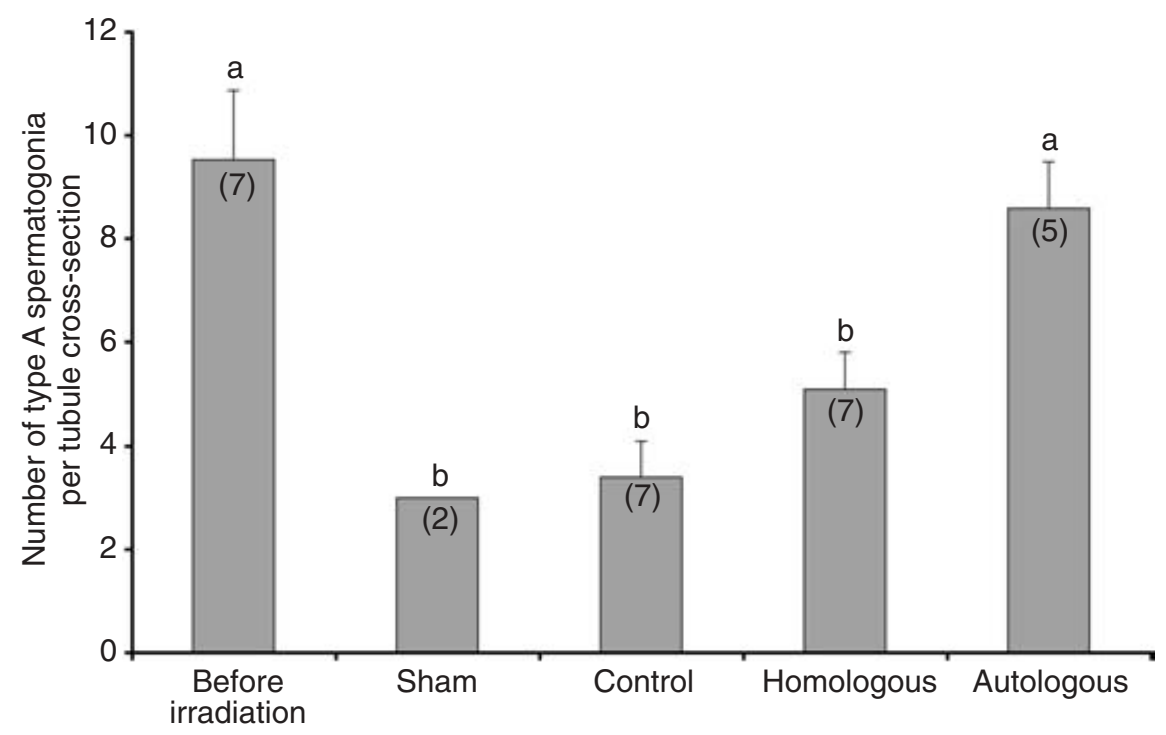

Fig. 5. Proportion of bovine type A spermatogonia as detected by Dolichos biflorus agglutinin staining. Data are presented as the number of type A spermatogonia per tubule cross-section. The results are the mean \pm SEM of two separate experiments. The values in the columns represent the number of testes examined. Note a significant $(P<0.01)$ increase was observed only after autologous transplantation.

\section{Discussion}

The present study demonstrates successful transplantation of bovine type A spermatogonia in recipient bulls resulting in full spermatogenesis after autologous transplantation. For successful transplantation of spermatogonial stem cells, three factors are important: (i) the donor cell suspension should contain as many spermatogonial stem cells as possible; (ii) recipient testes should contain as few endogenous spermatogenic cells as possible, while containing healthy somatic cells to support the transplanted spermatogonia; and (iii) an efficient transplantation procedure to insert the donor cells into the seminiferous tubules should be available. The present study used purified type A spermatogonia from 5-month-old calves as donor cells. At this age, the testes predominantly contain type A spermatogonia consisting of stem cells and early spermatogonial types of cell which are actively proliferating (Izadyar et al., 2002a). Our previous studies showed that these cells have a high stem cell activity as $>65 \%$ of tubules of recipient mouse testes could be colonized after several heterologous transplantation experiments. In addition, results of a study by Izadyar et al. (2003) showed extensive colony formation by these cells during a long-term culture. It was proposed that the donor cell suspensions used in our experiments contained relatively large numbers of spermatogonial stem cells compared with previous studies (Schlatt et al., 1999) in which a mixed germ cell population was used. Furthermore, in pigs (Honaramooz et al., 2002), donor cells were obtained from very young piglets (1-10 weeks) and because spermatogonia, for the first time, could be seen in the pig testis at 2 months of age (Hughes and Varley, 1980), many of the donor pigs may have contained only gonocytes and no spermatogonia. In addition, the cryopreservation method used by Izadyar et al. (2002b) was developed especially for type A spermatogonia and allowed survival of more cells after thawing compared with the conventional cryopreservation protocols used in those studies.

The results of the present study show that although autologous transplantation was successful, homologous transplantation was not effective. This finding is in contrast to observations in pigs and goats in which autologous and homologous transplantation brought about a similar repopulation of the recipient testes (Honaramooz et al., 2002, 2003). However, in these studies younger recipients were used than in the present study. The low efficiency of homologous transplantation in cows is most likely due to immunorejection, as in two calves a clear cellular infiltration was observed after homologous transplantation (data not shown). The calves used in the present study may already have been too old to allow successful homologous transplantation. The developmental stage of the recipient testis and in particular the formation of blood-testis barrier seems to have a critical role in homologous transplantation efficiency. It has been shown that homologous transplantation of mouse spermatogonia into the testes of adult recipient mice causes immunorejection, but when immature mice were used as recipients a complete restoration of spermatogenesis was achieved (Shinohara et al., 2003). 

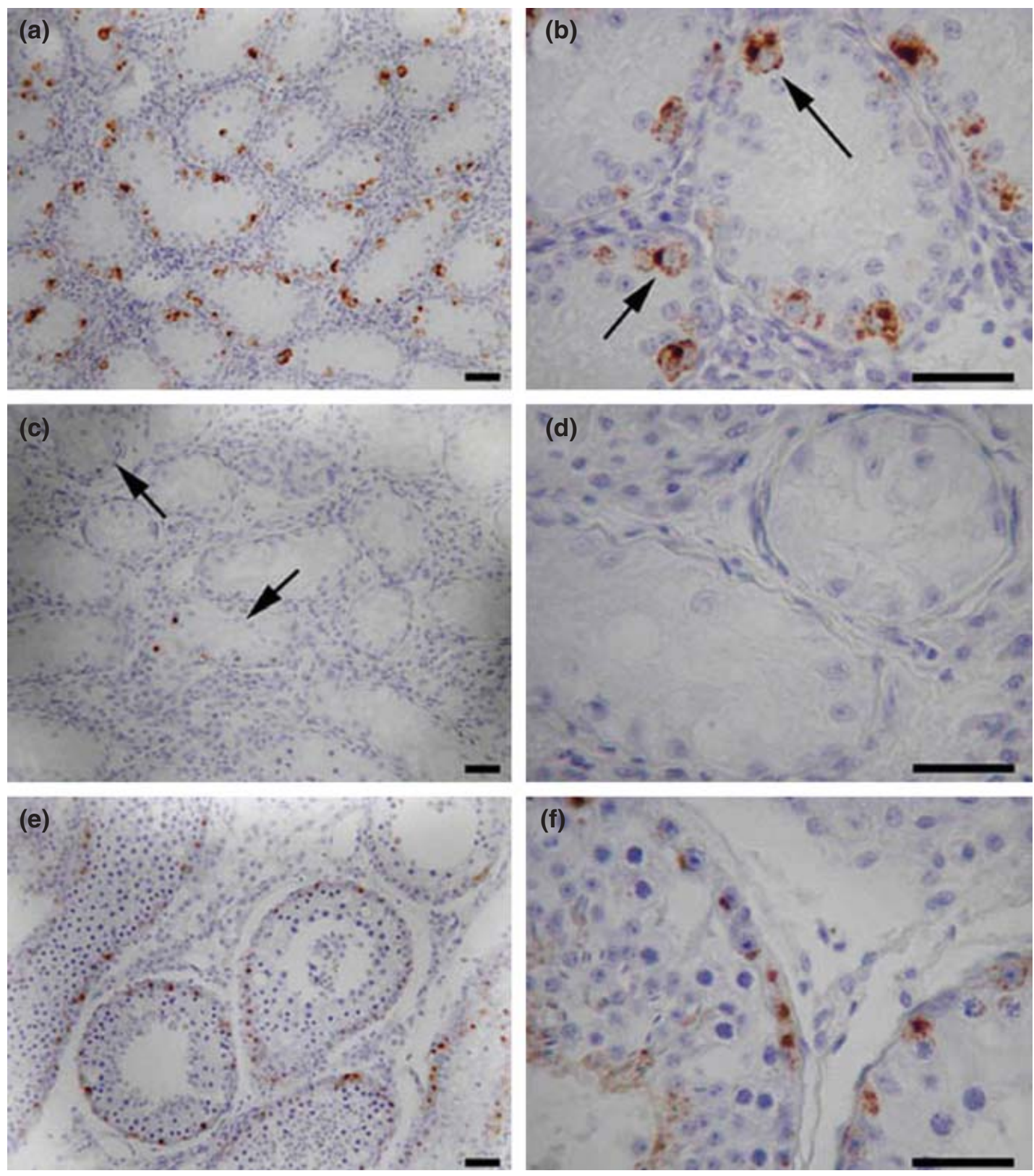

Fig. 6. Immunodetection of bovine type A spermatogonia using Dolichos biflorus agglutinin (DBA) staining before irradiation and 2.5 months after sham or spermatogonial transplantation. (a) Note the presence of DBA-positive cells in all tubules before irradiation (arrows shown in (b)). (b) The same section as in (a) at a higher magnification. (c) Tubule cross-section of a calf 2.5 months after sham transplantation. Note that after irradiation, few DBA positive cells are present in some tubules (arrows) and a majority of the tubules show only Sertoli cells. (d) The same section as in (c) at a higher magnification. (e) Tubule cross-section of a calf 2.5 months after autologous spermatogonial transplantation. Note the remarkable increase in number of DBA-positive cells. (f) The same section as in (e) at a higher magnification. Scale bars represent $50 \mu \mathrm{m}$.

Another important consideration in transplantation experiments is the depletion of endogenous spermatogenesis in the seminiferous tubules of the recipients. Local fractionated X-irradiation (1.5 and 12.0 Gy with a $24 \mathrm{~h}$ interval) was used to develop a protocol for the mouse testis that eliminates endogenous spermatogenesis in
$>95 \%$ of the seminiferous tubules (Creemers et al., 2002). As fractionated irradiation was not practical with calves, a single $X$-irradiation dose of 10-14 Gy was used. After these doses, about $60 \%$ of tubules were empty at 5 months after irradiation. At that time, the calves were 10 months old and the average testis mass of Holstein 
calves at this age is about $175 \mathrm{~g}$ (Amann, 1983). The weight of non-transplanted testes was very low and did not differ from that of testes at 5 months age. Only a small percentage of the tubules contained spermatocytes and very few spermatids were found. It is possible that because of extensive cell death among the endogenous stem cells after irradiation, these cells underwent a long period of self renewing divisions before producing differentiating germ cells as seen in the mouse (Van Beek et al., 1990).

However, a marked increase in testis mass was observed after autologous transplantation. As after hemicastration the weight of the other testis increases to compensate for this (Putra and Blackshaw, 1982; Jenkins and Waites, 1983; Lunstra et al., 2003), the enlargement of the testis after autologous transplantation might be due to the hemicastration. However, because calves that had been hemicastrated and irradiated but did not receive spermatogonia did not have enlarged testes (44 and $52 \mathrm{~g}$ ), this possibility seems unlikely. Interestingly, after autologous transplantation a substantial proportion of seminiferous tubules contained spermatids and spermatozoa. This finding indicates that after transplantation the donor stem cells relatively quickly restored the formation of differentiating germ cells within the recipient testes and also that the Sertoli cells in the irradiated recipient testes remained functional after the irradiation procedure and supported proliferation and differentiation of transplanted spermatogonial stem cells up to the final stages of spermatogenesis. Autologous spermatogonial transplantation in monkeys, in which the recipient testes had been prepared with X-ray irradiation, also resulted in a restoration of spermatogenesis (Schlatt et al., 2002).

Finally, it was noted that ultrasonography is essential for a successful rete testis injection in the bovine testis, which is in agreement with observations in large animals (Schlatt et al., 1999; Honaramooz et al., 2002). In addition, the results of the present study show that the application of contrast solution during ultrasonography of the testis considerably enhances the efficiency of the rete testis injection in this species. As this compound has no adverse effect on the viability of spermatogonia and has no obvious long-term effect on testis function, it can be safely used for spermatogonial transplantation protocols in large animals.

In summary, a successful spermatogonial stem cell transplantation procedure for domestic species was developed leading to a full spermatogenesis in the recipient testis. Optimization of the transplantation procedure using an ultrasound contrast solution, the source of the donor cells and the depletion of the recipient testes were essential factors in the effectiveness of the transplantation. The ineffeciency of homologous transplantation, which seems to be due to immunological rejection, needs to be studied in more detail. The results may have some industrial implications like preservation and replic- ation of germ line in valuable males as well as generation of transgenic animals for pharmaceutical purposes.

This work was supported by grants from the Netherlands Technology Foundation (STW). The authors would like to thank the RVV Amsterdam abattoir for supplying the testes. P. van Dijk from the Veterinary Faculty is acknowledged for supervision in anaesthesia and surgery. CR-Delta (Arnhem, The Netherlands) is acknowledged for providing the calves. R. B. van der Grift (Zeist, Netherlands) is greatly acknowledged for housing and keeping the animals during the experiments.

\section{References}

Almeida AG, Sargento L, Gabriel HM, da Costa JM, Morais J, Maderia F, David C, Oliveria J, da Cunha JC and Vagueiro MC (2002) Evaluation of aortic stenosis severity: role of contrast echocardiography in comparison with conventional echocardiography and cardiac catheterization Revista Portuguesa de Cardiologia 21 555-572

Amann RP (1983) Endocrine changes associated with onset of spermatogenesis in Holstein bulls Journal of Dairy Science 66 2606-2622

Boettger-Tong HL, Johnston DS, Russell LD, Griswold MD and Bishop CE (2000) Juvenile spermatogonial depletion (jsd) mutant seminiferous tubules are capable of supporting transplanted spermatogenesis Biology of Reproduction 63 1185-1191

Brinster RL and Avarbock MR (1994) Germline transmission of donor haplotype following spermatogonial transplantation Proceedings National Academy of Sciences USA 2411 298-11 302

Brinster RL and Zimmermann JW (1994) Spermatogenesis following male germ-cell transplantation Proceedings National Academy of Sciences USA 2411 303-11 307

Clouthier DE, Avarbock MR, Maika SD, Hammer RE and Brinster RL (1996) Rat spermatogenesis in mouse testis Nature 6581 418-421

Creemers LB, Meng X, den Ouden K, van Pelt AMM, Izadyar F, Santoro M, Sariola H and De Rooij DG (2002) Transplantation of germ cells from GDNF-overexpressing mice to host testes depleted from endogenous spermatogenesis by fractionated irradiation Biology of Reproduction $\mathbf{6 6}$ 1579-1584

de Rooij DG and Grootegoed JA (1998) Spermatogonial stem cells Current Opinion Cell Biology 6 694-701

Dobrinski I, Avarbock MR and Brinster RL (1999) Transplantation of germ cells from rabbits and dogs into mouse testes Biology of Reproduction 61 1331-1339

Dobrinski I, Avarbock MR and Brinster RL (2000) Germ cell transplantation from large domestic animals into mouse testes Molecular Reproduction and Development $\mathbf{5 7}$ 270-279

Ertl C and Wrobel KH (1992) Distribution of sugar residues in the bovine testis during postnatal ontogenesis demonstrated with lectin-horseradish peroxidase conjugates Histochemistry 97 161-171

Hansberg T, Wong KS, Droste DW, Ringelstein EB and Kay R (2002) Effects of the ultrasound contrast-enhancing agent levovist ( $r$ ) on the detection of intracranial arteries and stenoses in chinese by transcranial Doppler ultrasound Cerebrovascular Disease 14 105-108

Honaramooz A, Megee SO and Dobrinski I (2002) Germ cell transplantation in pigs Biology of Reproduction 66 21-28

Honaramooz A, Behboodi E, Blash S, Megee SO and Dobrinski I (2003) Germ cell transplantation in goats Molecular Reproduction and Development 64 422-428

Huckins C (1971) The spermatogonial stem cell population in adult rats. I. Their morphology, proliferation and maturation Anatomical Record $\mathbf{1 6 9}$ 533-557

Hughes PE and Varley MA (1980) Puberty in the male. In Reproduction in the Pig pp 173-186 Butterworth, UK

Izadyar F, Spierenberg GT, Creemers LB, den Ouden K and de Rooij DG (2002a) Isolation and purification of type A spermatogonia from the bovine testis Reproduction 124 85-94 
Izadyar F, Matthijs-Rijsenbilt JJ, den Ouden K, Creemers LB, Woelders H and de Rooij DG (2002b) Development of a cryopreservation protocol for type A spermatogonia Journal of Andrology 23 537-545

Izadyar F, den Ouden K, Creemers LB, Posthuma G, Parvinen M and de Rooij DG (2003) Proliferation and differentiation of bovine type A spermatogonia during long-term culture Biology of Reproduction $\mathbf{6 8}$ 272-281

Jenkins $\mathbf{N}$ and Waites GM (1983) Effects of hemi-castration at various ages and of oestradiol-17 beta on plasma concentrations of gonadotrophins and androgens, testicular growth and interstitial cell responses in prepubertal lambs Journal of Reproduction and Fertility 68 325-334

Lok D, Weenk D and de Rooij DG (1982) Morphology, proliferation and differentiation of undifferentiated spermatogonia in the Chinese hamster and the ram Anatomical Record 203 83-99

Lunstra DD, Wise TH and Ford JJ (2003) Sertoli cells in the boar testis: changes during development and compensatory hypertrophy after hemi castration at different ages Biology of Reproduction 68 140-150

Nagano M, McCarrey JR and Brinster RL (2001) Primate spermatogonial stem cells colonize mouse testes Biology of Reproduction 641409 1416

Nagano M, Patrizio P and Brinster RL (2002) Long-term survival of human spermatogonial stem cells in mouse testes Fertility Sterility $\mathbf{6}$ 1225-1233

Ogawa T, Dobrinski I, Avarbock MR and Brinster RL (1999a) Xenogeneic spermatogenesis following transplantation of hamster germ cells to mouse testes Biology of Reproduction 60 515-521

Ogawa T, Dobrinski I and Brinster RL (1999b) Recipient preparation is critical for spermatogonial transplantation in the rat Tissue Cell 5 461472

Ohta H, Yomogida K, Dohmae K and Nishimune Y (2000) Regulation of proliferation and differentiation in spermatogonial stem cells: the role of C-kit and its ligand SCF Development 10 2125-2131

Ohta H, Yomogida K, Tadokora Y, Tohda A, Dohmae K and Nishimune $\mathbf{Y}$ (2001) Defect in germ cells, not in supporting cells, is the cause of male infertility in the jsd mutant mouse: proliferation of spermatogonial stem cells without differentiation International Journal of Andrology 1 15-23

Putra DK and Blackshaw AW (1982) Morphometric studies of compensatory testicular hypertrophy in the rat after hemi castration Australian Journal of Biological Science 35 287-293

Schlatt S, Rosiepen G, Weinbauer GF, Rolf C, Brook PF and Nieschlag E (1999) Germ cell transfer into rat, bovine, monkey and human testes Human Reproduction 14 144-150

Schlatt S, Foppiani L, Rolf C, Weinbauer GF and Nieschlag E (2002) Germ cell transplantation into X-irradiated monkey testes Human Reproduction 17 55-62

Shinohara T, Avarbock MR and Brinster RL (2000a) Functional analysis of spermatogonial stem cells in Steel and cryptorchid infertile mouse models Developmental Biology 2 401-411

Shinohara T, Orwig KE, Avarbock MR and Brinster RL (2000b) Spermatogonial stem cell enrichment by multiparameter selection of mouse testis cells Proceedings National Academy of Sciences USA 15 8346-8351

Shinohara MK, Ogonuki N, Inoue K, Ogura A, Toyokuni S, Honjo T and Shinohara T (2003) Allogeneic offspring produced by male germ line stem cell transplantation into infertile mouse testis Biology of Reproduction 68 167-173

Van Beek ME, Meistrich ML and de Rooij DG (1990) Probability of selfrenewing divisions of spermatogonial stem cells in colonies, formed after fission neutron irradiation Cell Tissue Kinet 23 1-16

van Pelt AM, Roepers-Gajadien HL, Gademan IS, Creemers LB, de Rooij DG and van Dissel-Emiliani FM (2002) Establishment of cell lines with rat spermatogonial stem cell characteristics Endocrinology 143 18451850

Received 31 March 2003.

First decision 2 June 2003.

Revised manuscript received 17 July 2003.

Accepted 27 August 2003. 